\title{
The two-stage filtering of airborne laser data in a frequency domain
}

\section{Urszula Marmol}

\author{
Department of Geoinformation, Photogrammetry and Remote Sensing of Environment \\ AGH University of Science and Technology in Krakow \\ 30 Mickiewicza Al., 30-059 Krakow, Poland \\ e-mail: entice@agh.edu.pl
}

Received: 29 April 2010/Accepted: 28 December 2010

\begin{abstract}
In the paper a frequency method of filtering airborne laser data is presented. A number of algorithms developed to remove objects above a terrain (buildings, vegetation etc.) in order to obtain the terrain surface were presented in literature. Those all methods published are based on geometrical criteria, i.e. on a specific threshold of elevation differences between two neighbouring points or groups of points. In other words, topographical surface is described in a spatial domain.

The proposed algorithm operates on topographical surface described in a frequency domain. Two major tools, i.e. Fast Fourier Transform (FFT) and digital filters are used. The principal assumption is based on the idea that low frequencies are responsible for a terrain surface, while high frequencies are connected to objects above the terrain. The general guidelines of this method were for the first time presented at (Marmol and Jachimski, 2004). Due to the fact that the preliminary results showed some limitations, two-stage filtering algorithm has been introduced. The frequency filter was modified in such a manner that different filter parameters are used to detect buildings than those to recognize vegetation.

In the first stage of data processing the filtering concerning elimination of points connected with urban areas was applied. The low-pass filter with parameters determined for urban area was used for the whole tested terrain in that stage. The purpose of the second stage was to eliminate vegetation by using the filter for forest areas.

The presented method was tested by using data sets obtained in the ISPRS test on extracting DTM from point clouds. The results of using the two-stage algorithm were compared with both reference data and with filtering results of eight method reported to ISPRS test.

A numerical comparison of the filter output with a reference data set shows that the filter generates DTM of a satisfactory quality. The accuracy of DTM produced by the frequency algorithm fits the average accuracy of eight methods reported in the ISPRS test.
\end{abstract}

Keywords: laser scanning, terrain surface, algorithms, automation, filtering, FFT

\section{Introduction}

The literature concerning laser scanner data filtering reports many algorithms developed to remove objects above a terrain (buildings, vegetation etc.) in order to obtain the true 
terrain surface. There are, for example: iterative robust linear prediction (Pfeifer et al., 2001), adaptive TIN (Axelsson, 2000), morphological operators (Vosselman, 2000; Chen et al., 2007), active surface model or flakes (Elmqvist, 2002; Borkowski, 2005; Borkowski and Józków, 2007), wavelets (Borkowski and Keller, 2006; Wei and Bartels, 2006). Unfortunately, in order to completely remove non-ground points, the filtering process often requires interactive editing. Thus, the filtering is still a challenging task and further research is needed to improve its efficiency.

This paper proposes a frequency approach for filtering, derived from the digital signal processing theory. The general guidelines of the new method were for the first time presented at Marmol and Jachimski (2004). There was reported that in the trial run filtering, errors appeared first of all in forest areas. To overcome this limitation, the frequency filter was modified in such a manner that filter parameters used to detect buildings differ from those applied to detect vegetation.

In the first part of this paper digital signal processing theory is briefly introduced and then theoretical assumptions of the algorithm are described. In the empirical studies the two-stage algorithm was implemented and tested using two test fields: Vaihingen test field and Stuttgart city centre. The results of the tests are presented in the second part of the paper. Finally, the most important conclusions are drawn.

\section{Theory}

The terrain surface in discrete representation, i.e. DTM, describes the elevation of measured point in a position-oriented manner, as a function of its position $(x, y)$. Using conventional mathematical terminology, one could say that such function represents the terrain in the space domain.

The terrain could also be represented in the frequency domain, where a surface is defined as the sum of sinusoidal components for different frequencies. The frequency description reveals some interesting properties of terrain, so it is possible to distinguish between various types of surfaces.

\subsection{Fast Fourier Transform}

The spectrum analysis is widely applied in electrical engineering. It is used to examine frequencies in signals. The signal is represented mathematically as a function of one or more variables. The discrete terrain surface can be interpreted as a signal, so it is reasonable to apply the spectrum technique to describe and deal with terrain surface.

The spectrum describes the relationship between space domain and frequency domain, and can be determined as follows:

$$
X(k)=\sum_{n=0}^{N-1} z(n) \cdot e^{-j n k \cdot 2 \pi / N}=X_{\text {real }}(k)+j \cdot X_{\text {imag }}(k)
$$


where

$$
\begin{aligned}
& X_{\text {real }}(k)=\sum_{n=0}^{N-1} z(n) \cdot \cos (n k \cdot 2 \pi / N) \\
& X_{\text {imag }}(k)=\sum_{n=0}^{N-1} z(n) \cdot \sin (n k \cdot 2 \pi / N)
\end{aligned}
$$

with $N$ - total number of measured points; $j=\sqrt{ }-1 ; z(n)$ - elevation of measured point $n$.

The FFT function does not have a simple physical interpretation. Some conversion of spectrum is necessary in order to determine physical parameters.

The power spectral density is estimated as the modulus-squared of the FFT of the data divided by the number of the data points. The power spectrum values are obtained using the formula

$$
P(k)=\frac{1}{N}|X(k)|^{2}
$$

A periodogram, as an estimator of this function, provides information on the content of frequencies of a set of elevation data. It is possible to distinguish between different types of terrain by examining their periodograms. Thus, "noise" (objects above the terrain) can be separated from the true elevations of the surface (to determine the so-called cut-off frequency).

\subsection{Digital filters}

Filtering, that is a commonly used procedure in signal processing, has received a great deal of attention in many applications. Filter is a function that cuts those parts of a signal that are considered unnecessary or extracts the needed frequency information from a signal.

A digital filter is mathematically defined as an operator that converts the input data $z(n)$ into the output data $z_{F}(n)$. The filter can be defined as

$$
z_{F}(n)=P[z(n)]
$$

In the spatial domain the digital filter can be presented as a discrete convolution of the input signal with the impulse response $h(n)$

$$
z_{F}(n)=h(n) * z(n)
$$

Digital filter can also be described in the frequency domain as a so-called frequency response

$$
H(f)=\sum_{n=0}^{N-1} h(n) \cdot e^{-j n k \cdot 2 \pi / N}
$$


In order to design filters the knowledge of the cut-off frequency is frequently needed. The cut-off frequency separates the pass band from the stop band. There are several types of filters: low-pass, band-pass, band-stop, high-pass. A low-pass filter passes low frequencies and simultaneously blocks high frequencies while a high-pass filter passes high frequencies and simultaneously blocks low frequencies. A band-pass filter or band-stop filter are combinations of a high- and low-pass filters.

\section{Filtering algorithm for terrain surface extraction}

The principal assumption of the algorithm is based on the idea, that low frequencies are responsible for the run of topographical surface, while high frequencies are related to the objects. Therefore, it is necessary to design a low-pass filter to be able to determine a realistic DTM from airborne laser data (Marmol, 2002). The method can be summarized in the following phases:

\section{- Interpolation of raw data to obtain a regular grid}

The theory of digital transformation of signals is based on the assumption, that a considered flow of the initial data is a set of equally distributed data. To fulfil that assumption it is necessary to generate a regular grid of points out of the cloud of points recorded during the laser scanning, using an interpolation technique. As it is well known, the laser data comprise not only ground points, but also the points located on various field objects. An interpolation process can contribute to the significant falsification of the topographical surface run, and can make the filtration process difficult. To reduce the errors the Nearest Neighbour interpolation algorithm was applied to the original data.

\section{- Trend analysis}

The trend must necesarilly be removed before applying FFT, to omit the influence of trend during estimation of spectrum. The trend analysis consists in a least squares approximation of a set of points with the use of a polynomial functions. The degree of fitting the data by the trend is determined by the determination coefficient. First, the statistics of the diferences between positions of measured points and trend surface is calculated. Then, it is compared with the statistics of diferences between positions of measured points and horizontal plane on mean elevation. That way the determination coefficient is obtained (Kokesz, 1984).

- Designing digital FIR filters by the determination of filtering parameters, i.e. the cut-off frequency and the filter order

A Finite Impulse Response (FIR) filter is a type of a discrete-time filter. A simple way to design a FIR filter is through windowing of the inverse Fourier transform of 
the desired frequency response. The FIR filter window design technique involves the following steps:

1. Start with the desired frequency response $H(f)$ - by the determination of the cut-off frequency $f_{c}$;

2. Obtain $h(n)$ via the inverse Fourier transform of $H(f)$;

3. Window $h(n)$ to obtain FIR filter coefficients; the size of a window is equal to the filter order.

The determination of filter parameters, i.e. the cut-off frequency and the filter order is the most important phase of the proposed algorithm.

- Filtering process and classification of the cloud of points into two groups: object points and ground points

\subsection{Determination of the cut-off frequency}

Discrete spatial data are described in the frequency domain by applying FFT to obtain power spectral density function. A periodogram, as an estimate of that function, provides required information on frequencies of a set of elevation data.

In order to evaluate the cut-off frequency, some tests have been carried out. The test sample, including just a topographical surface has been selected and a periodogram for this area has been calculated (Fig. 1). Similar procedures have been carried out for the areas covered with selected types of field objects (Fig. 2).
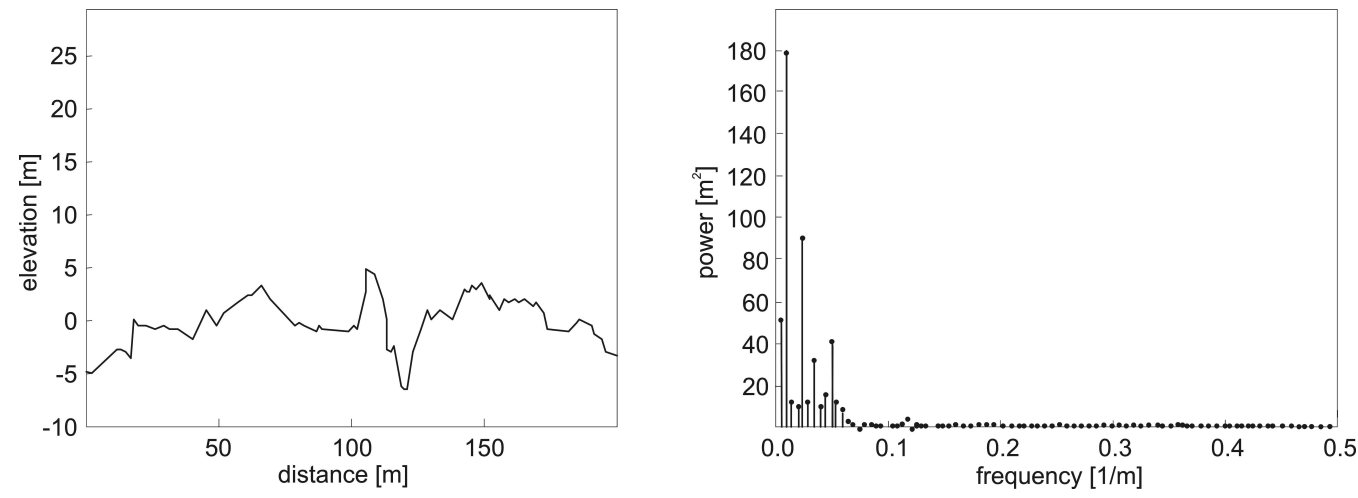

Fig. 1. The "true" terrain profile and its periodogram

The periodogram of the "true" topographic surface has high values concentrated at low frequencies (Fig. 1). The values of that periodogram decrease rapidly as the higher frequency zone approached.

The periodogram of objects above the ground has significant values concentrated at all frequencies excluding very low frequencies (Fig. 2). It follows that the high frequency zone of cumulative periodogram for topographic surface and objects can be regarded as a result of noise, i.e. objects above the terrain. 

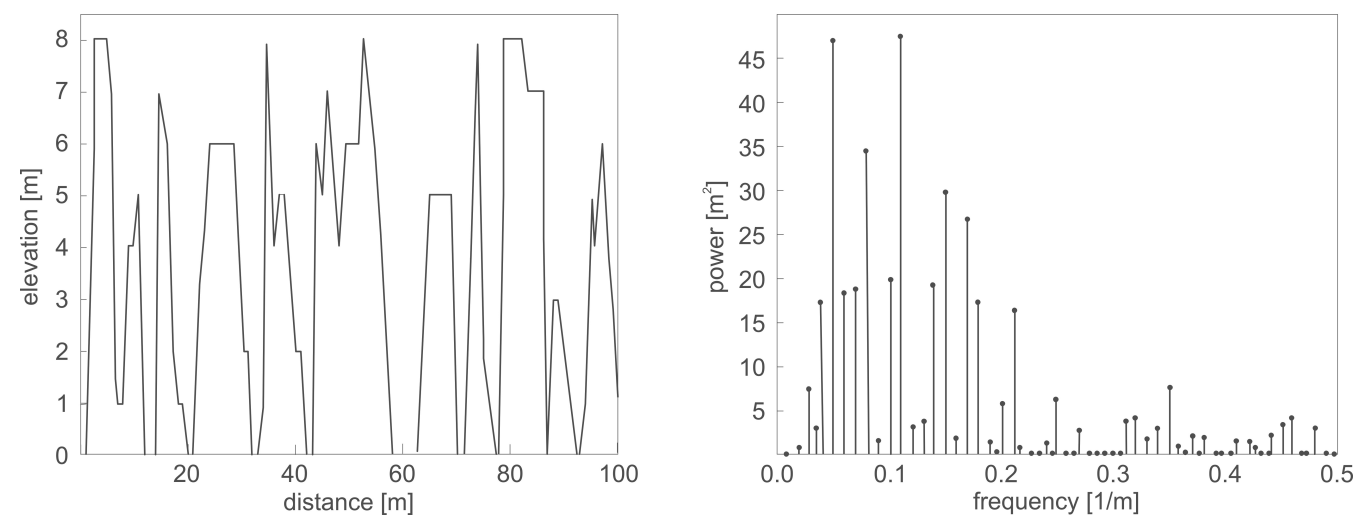

Fig. 2. The profile of objects above a ground and its periodogram

It is obvious that practically it is not possible to strictly determine the cut-off frequency, because periodograms for a topographic surface and objects partly coincide with each other. Therefore, a filtering process has to proceed iteratively.

\subsection{Determination of the filter order}

The filter order determines the size of the neighbourhood, i.e. a set of points used to calculate value of filtered point. The choice of the size of the neighbourhood is an important issue to achieve reliable and accurate results in a filtering process. If a small window size is used, most of the ground points will be preserved, but only small non-ground objects will effectively be removed. In such case the points corresponding to the large-sized building cannot be removed. On the other hand, if the window size is large, the filter tends to over-remove the ground points.

In the developed method, a geostatistic theory is used for automatic determination of the optimal window size.

Geostatistics is a branch of statistics that deals specifically with spatial relationships. The basis of geostatistics is a study of the spatial variability of data measured in three-dimensional space. The structure of variability is described in a synthetic form by a so-called semivariogram that is a measure of average dissimilarity between measured points as a function of spatial separation.

For regular grid data the semivariance values $\gamma(d)$ are given by the equation

$$
\gamma(d)=\frac{\sum_{i=1}^{n}\left[z\left(x_{i}\right)-z\left(x_{i}+d\right)\right]^{2}}{2 n}
$$

where $z\left(x_{i}\right), z\left(x_{i}+d\right)$ are the elevation values of the points separated by the distance $d$; $n$ is the number of pairs of points separated by the distance $d$.

In order to make a quantitative assessment possible, it is necessary to approximate an empirical semivariogram by a simple analytical function, that can be treated as 
a geostatistical variability model. In geostatistics, there is a number of semivariogram models, e.g. linear, spherical, logarithmic, Gaussian, exponential, etc. (David, 1977). The analysis of theoretical semivariogram provides a value of the sill, the range of influence, and the nugget effect (see Fig. 3). The range of influence is the most interesting feature and can be used as a measure of spatial dependency. This range determines the distance at which points become independent of one another. In this study, the range of influence is used to predict the optimal filter order applied in the filtering process.

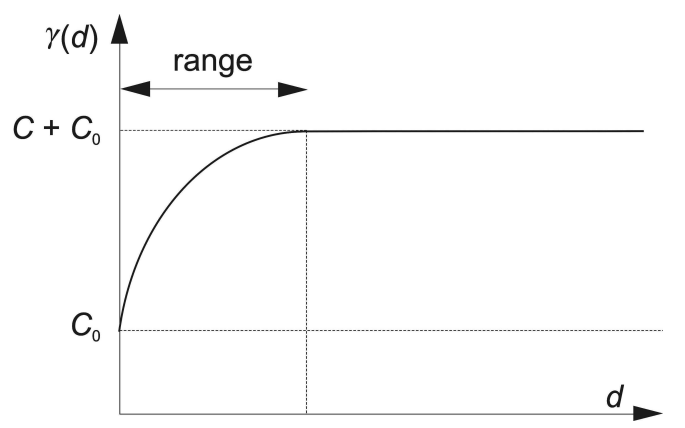

Fig. 3. Theoretical semivariogram: $C_{0}$ - the nugget effect - variations at a much smaller scale than any of the measured pairwise distances; $C$ - the sill value; range - the influence range; $d$ - distance

\subsection{Two-stage algorithm for terrain surface extraction}

The results of preliminary one-step filtering tests showed that the algorithm worked well for urban areas, while the filtering errors appeared in forest areas. In order to overcome this problem the algorithm has been modified. The main parameters of the frequency algorithm are the cut-off frequency and the filter order. The test analysis performed showed that it is not reliable to work with one set of parameters in areas with different objects above terrain. A possible solution would thus be to implement a different sets of filter parameters for urban and vegetation areas. It is obvious, that the selection of the filter order (window size) and the cut-off frequency is critical to achieve good results when applying the frequency filter.

\section{Experiments}

The presented method was tested by using data sets obtained in the ISPRS test on getting DTM from point clouds (Sithole and Vosselman, 2004). The main objective of this project was to determine the functionality of the filtering algorithms for different objects and terrain configuration. 


\subsection{Test data}

The laser data used in the study are from the Vaihingen test field and Stuttgart city centre, that was available within the second phase of the OEEPE project on laser scanning (Petzold and Axelsson, 2000). These areas were scanned with an Optech ALTM scanner, and first and last pulse data were recorded together with the intensity of returned pulses. The test data covers various land-use and land-cover types including buildings, vegetation, rivers, roads, railroads, bridges, etc. The point spacing was $1.0-1.5 \mathrm{~m}$ for urban sites and $2.0-3.5 \mathrm{~m}$ for rural sites.

The algorithm was tested carefully on 3 test sets (site 11, 22 and 51). A detailed description of the test data can be found in (Vosselman 2003). Exemplary test data set is shown in Figure 4. These test sets were selected as containing different features and slopes. In the first step of executing the algorithm the raw data was interpolated in order to obtain a regular grid.

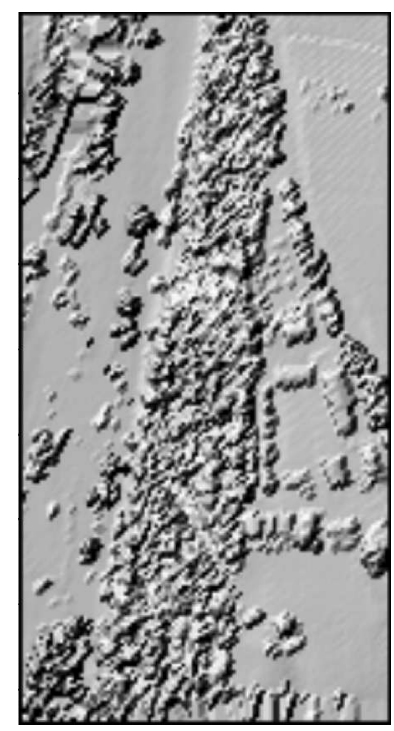

Fig. 4. Exemplary test site

\subsection{Reference data set}

The reference data provided by the organizers of the international experiment (Vosselman, 2003) were generated by the manual filtering of the cloud of laser data. In this process, the operator analysed manually all points measured with laser with the aid of aerial photographs. After manual filtering, all points were divided into two groups: ground points and object points. 


\subsection{Design of digital filter for urban and forest areas}

The proposed algorithm is described in detail for the example of the test site 51 . The frequency algorithm proceeded in two stages. In the first stage the buildings from the build-up areas were deleted and in the second stage - vegetation. In order to choose correct parameters for design digital filters, the training samples of urban and forest areas were selected. In the first phase the cut-off frequencies have been determined by the analysis of the periodograms for urban areas and forest areas.
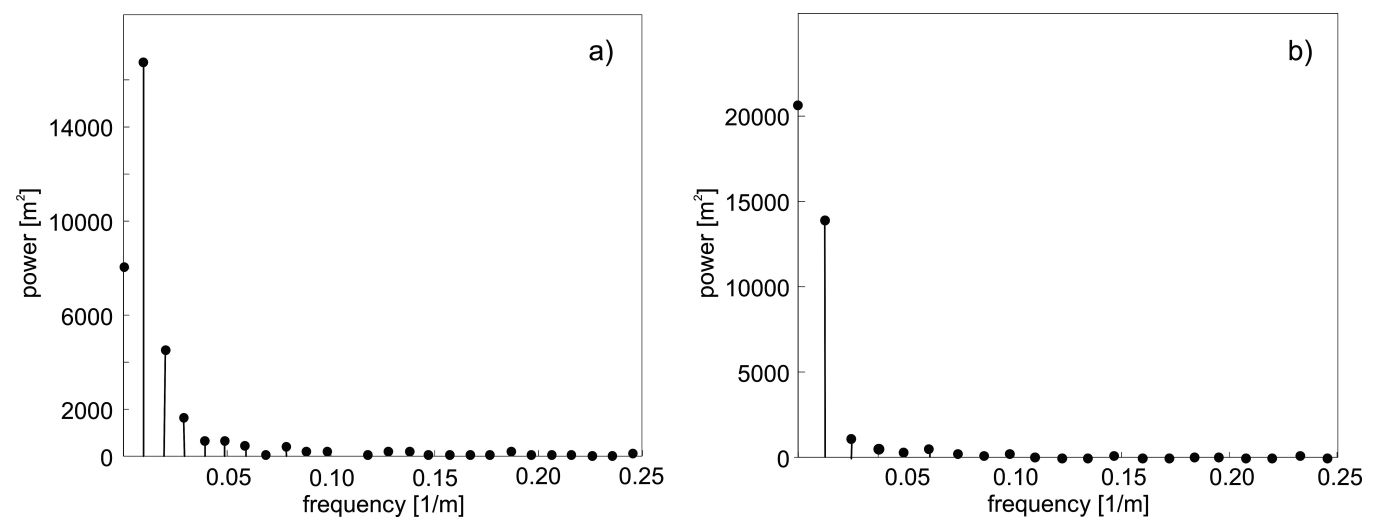

Fig. 5. Periodograms for urban area (a) and forest area (b), respectively

The optimum cut-off frequency for urban area and forest area for the analysed test site (Fig. 5) is equal to $0.025[1 / \mathrm{m}]$ and $0.01[1 / \mathrm{m}]$, respectively.
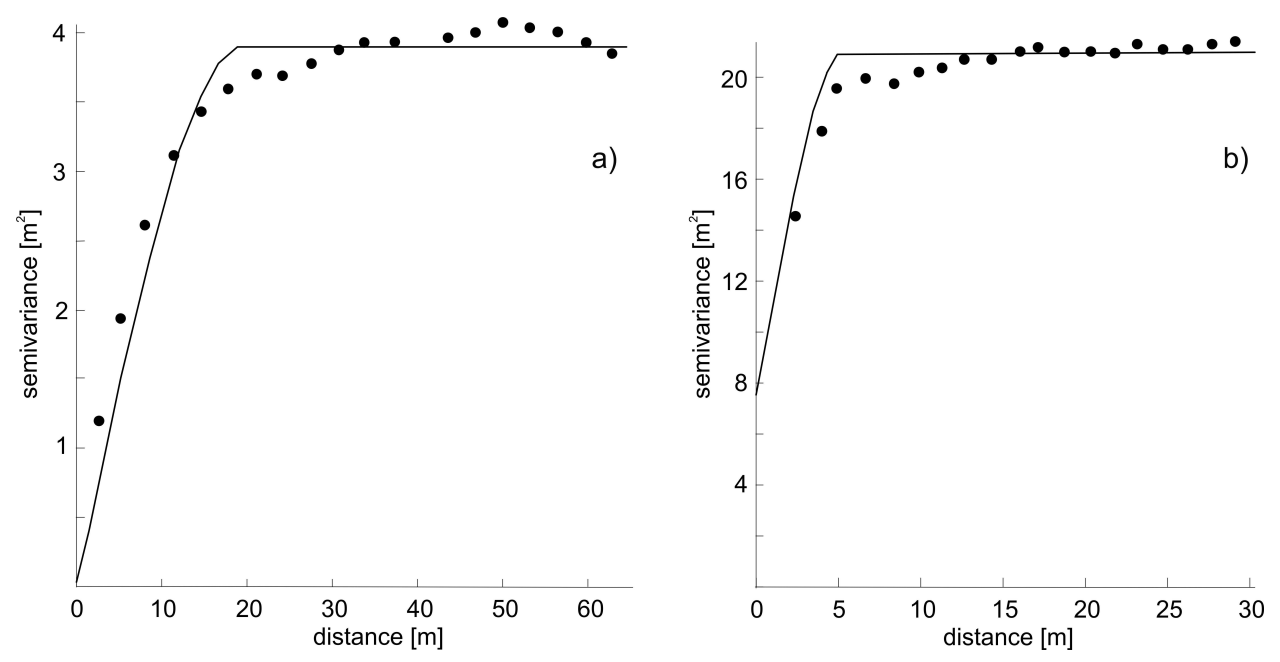

Fig. 6. Semivariograms for urban area (a) and forest area (b), respectively 
In the next phase semivariograms have been calculated and two ranges of influence have been determined for urban and forest areas separately.

The empirical semivariogram for urban area was fitted by the spherical model (David, 1977). This model is the most frequently used. The values for the sill, the range, and the nugget effect were obtained by least squares fitting, i.e. by minimizing the mean square deviation. The range of influence was calculated as equal to 20 cells.

The similar procedure was carried out for the forest areas. The experimental values were also fitted by the spherical model using the least squares method. The range of influence is equal to 8 cells, thus it significantly differs from the value determined for urban areas.

The calculated ranges of influence were used during the filtering of laser scanner data as the values of filter order.

\subsection{Filtering process}

The filtering process consists of two stages. In the first stage the filtering concerns the elimination of points connected with urban areas. The low-pass filter with parameters determined for urban area was used for the whole tested terrain in that stage. The points connected with buildings were properly filtered.

The correctness of building filtering was confirmed by using first and last laser pulse. The height difference between first and last pulse smaller than $0.25 \mathrm{~m}$ indicate the occurrence of the topographical surface or buildings. In order to clearly determine buildings, a next criterion has been introduced. It is based on DTM, which was developed with the use of the filter for urban areas. The height difference between first pulse and the mentioned DTM was determined. Differences larger than $3 \mathrm{~m}$ indicate the occurrence of a building.

All the above-mentioned criteria allowed to extract buildings with the highest possible reliability.

The filter with parameters determined using training samples of urban areas is not correct for vegetation. On the other hand, the filter for a forest area allows to identify vegetation correctly, but it generates errors in urban areas. Therefore, it is reasonable to apply the filter for vegetation to the set of data from which the points located on buildings were already excluded. Those eliminated points have been replaced by the heights interpolated on the basis of the ground points of neighbouring nodes of the DTM grid.

In the second stage of filtering, the vegetation filter was applied; the points belonging to trees were identified and replaced by interpolated ground points.

The results obtained show that those two stages: the filtering with urban filter and vegetation filter, allow to correctly eliminate non-topographical objects. After the whole filtering process, a regular DTM grid with the ground elevations assigned to it was obtained. 


\subsection{Accuracy assessment}

According to Sithole and Vosselman (2004) two types of misclassification were selected: type I errors and type II errors. Type I errors reflect the misclassification of terrain points as object points and type II errors reflect the misclassification of object points as terrain points.

Reference samples were used to quantitatively assess the accuracy at all analysed sites. The obtained results were compared with reference data set (see Section 4.2). The type I, type II, and total errors were calculated for each sample. Due to the limitation of space, the accuracy estimate of sample 51 only is shown (Table 1 and Table 2).

All tested points filtered with the frequency algorithm were divided into two groups: object points and ground points.

Table 1. Filtering results: (1.1) - number of ground points that have been correctly identified as ground; (1.2) - number of type I errors; (1.3),(2.3) - total number of ground points and object points in the reference data, respectively; (1.4), (2.4) - proportions of ground points and object points in the reference data in the relation to the tested data, respectively; (2.1) - number of type II errors; (2.2) number of object points that have been correctly identified as objects; (3.1), (3.2) - total number of ground points and object points in the filtered data, respectively; (3.3) - total number of tested points; (4.1), (4.2) proportions of ground points and object points in the filtered data in relation to the tested data, respectively

\begin{tabular}{|c|c|c|c|c|c|c|}
\hline & & & \multirow{2}{*}{\multicolumn{4}{|c|}{ Filtered data }} \\
\hline & & & & & & \\
\hline & & & 1 & 2 & 3 & 4 \\
\hline & & & Ground points & Object points & Total & Percentage [\%] \\
\hline \multirow{4}{*}{ Reference data } & 1 & Ground points & 12087 & 512 & 12599 & 77.3 \\
\hline & 2 & Object points & 123 & 3569 & 3692 & 22.7 \\
\hline & 3 & Total & 12210 & 4081 & 16291 & 100.00 \\
\hline & 4 & Percentage [\%] & 74.95 & 25.05 & 100.00 & \\
\hline
\end{tabular}

Additionally, for the groups of type I and type II errors the following statistical parameters were calculated: the magnitude of minimum and maximum errors, the mean and the standard deviation (Table 2).

Table 2. Filtering results for type I and type II errors; total error equals to $3.9 \%$

\begin{tabular}{|c|c|c|c|c|c|}
\hline Type of errors & Percentage [\%] & Min [m] & Max [m] & Mean [m] & Std. dev.[m] \\
\hline \hline I & $\underline{4.06}$ & -1.28 & 1.53 & -0.17 & 0.59 \\
\hline II & $\mathbf{3 . 3 3}$ & -2.79 & 1.68 & -0.25 & 0.47 \\
\hline
\end{tabular}

Type I and type II errors of three samples for frequency algorithm were summarized in Table 3. It shows that the best results were obtained for site 51 while the worst for site 11 . 
Table 3. Percentage of type I and type II errors at sites 11, 22 and 51

\begin{tabular}{|c|c|c|}
\hline Site No & Type I error [\%] & Type II error [\%] \\
\hline 11 & 30.10 & 3.20 \\
\hline 22 & 10.18 & 7.22 \\
\hline 51 & 4.06 & 3.33 \\
\hline
\end{tabular}

The detailed analysis of obtained results revealed that filtering process of buildings proceeds correctly. All buildings in the tested areas were correctly extracted with the use of frequency urban filter, and eliminated.

Detected errors of both I and II type are connected with the occurrence of vegetation. The careful analysis of single profiles showed that some terrain forms (i.e. very small hills) reveal a similar characteristics as single trees.

The frequency algorithm eliminated those points as probable object points. Unfortunately, an attempt to include additional information about intensity of laser pulse, did not contribute to the improvement of algorithm operation in these fragments.

There were also few type II errors, caused by insufficient filtering of vegetation. Those errors are mainly caused by the low penetration rate in case of dense clusters of deciduous forest.

\subsection{Comparison with other filtering algorithms}

The presented algorithm was compared with eight methods reported in the ISPRS test. Figure 7 shows graphically both type I errors and type II errors for two test areas: 51, and 11 , respectively.
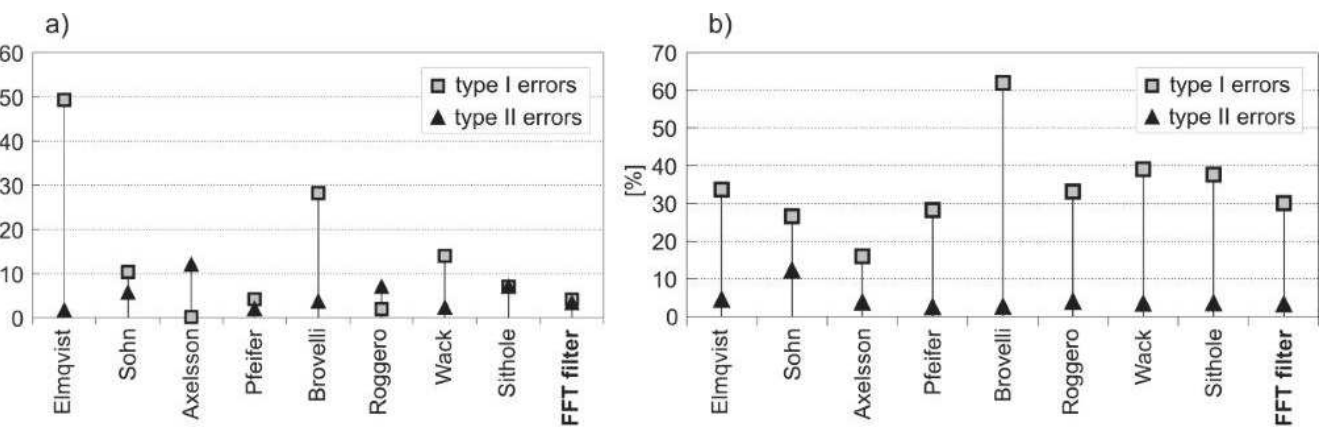

Fig. 7. Comparison of the type I and type II errors for all tested algorithms for site 51

The results presented in Figure 7 show that the proposed algorithm is placed in the middle of the ISPRS ranking as regards of type I errors and type II errors.

It thus can be concluded that the proposed method provides quite accurate results of filtering. 


\section{Conclusions}

The developed algorithm proved, that frequency domain analysis of terrain data can be a very useful tool for eliminating non-topographical objects.

Comparison of the filter output with a reference data set demonstrates very promising results for urban areas. Almost all buildings are separated very precisely by using the filter with correct parameters for urban area.

Implementation of two-stage filtering algorithm also improved significantly the accuracy of filtering of forest areas. Some errors, that revealed in forest areas are caused by the similar characteristics of some terrain forms to those of single trees (type I errors) and the low penetration rate in case of dense clusters of deciduous forest (type II errors).

Comparison of the presented algorithm with eight filtering methods reported in the ISPRS test shows, that the proposed algorithm is placed in the middle of the ISPRS ranking as regards of type I errors and type II errors. A detailed analysis for site 51 reveals, that the proposed algorithm is placed third as regards type I errors, after Axelsson's and Roggerro's methods. For type II errors frequency method is placed fourth, after Elmqvist's, Pfeifer's and Wack's methods. Analysis for site 11: type I errors - fourth place, after Axelsson's, Pfeifer's and Sohn's methods, type II errors third place, after Pfeifer's and Brovelli's methods.

The proposed algorithm is highly automatic and requires small human interference. The disadvantage of the method is the necessity of regularization of original data as well of selection training samples of urban and forest areas to choose correct parameters for design digital filters.

Summarising, a numerical comparison of the filter output with a reference data set shows that the filter generates DTM of a satisfactory quality. The frequency algorithm represents a quite efficient method for automatic classification of LIDAR data.

\section{Acknowledgments}

The research was done in the framework of the statutory project No 11.11.150.949/10 of the AGH University of Science and Technology in Krakow. Special thanks are given to George Sithole and Norbert Pfeifer of Delft University of Technology for providing data for the work presented here. Also, the author would like to thank TopoSys for providing some additional materials that helped to estimate frequency algorithm reliability. 


\section{References}

Axelsson P., (2000): DEM generation from laser scanner data using adaptive TIN models, International Archives of Photogrammetry and Remote Sensing, 33, (Part 4B), pp. 110-117.

Borkowski A., (2005): Airborne laser scanning data filtering using active surface method (in Polish), Roczniki Geomatyki, T. 3, z. 4, pp. 35-42.

Borkowski A, Józków G., (2007): Correctness evaluation of the flakes based filtering method of airborne laser scanning data (in Polish), Archiwum Fotogrametrii, Kartografii i Teledetekcji, Vol. 17a, pp. 83-92.

Borkowski A., Keller W. (2006): An Attempt to ALS-data filtering in wavelet domain, $8^{\text {th }}$ Bilateral Geodetic Meeting Poland-Italy. Wrocław, 22-24 June. http://www.geo.ar.wroc.pl/8bgmpi/

Chen Q., Gong P., Baldocchi D., Xie G., (2007): Filtering Airborne Laser Scanning Data with Morphological Methods, Photogrammetric Engineering \& Remote Sensing, Vol. 73, No 2, pp. 175-185.

David M., (1977): Geostatistical ore reserve estimation, Elsevier, Amsterdam, pp. 102-112.

Elmqvist M., (2002): Ground surface estimation from airborne laser scanner data using active contour models, ISPRS, Commission III, Symposium Photogrammetric Computer Vision, 9-13 September, Graz, Austria, pp. 114-118.

Kokesz Z., (1984): Geostatistical characterization of sulphur deposits for the purpose of identifying and estimating resources (in Polish), PhD Thesis, AGH University of Science and Technology, Krakow, Poland.

Marmol U., (2002): A frequency analysis as a filtering method of topographical profiles (in Polish), Archiwum Fotogrametrii, Kartografii i Teledetekcji 12a, pp. 257-268.

Marmol U., Jachimski J., (2004): A FFT based method of filtering airborne laser scanner data, International Archives of Photogrammetry, Remote Sensing and Spatial Information Sciences, 35 (Part 3B), pp. 1147-1152.

Petzold B., Axelsson P., (2000): Results of the OEEPE WG on laser data acquisition, International Archives of Photogrammetry and Remote Sensing, 33 (Part 3B), pp. 718-723.

Pfeifer N., Stadler P., Briese Ch., (2001): Derivation of digital terrain models in SCOP++ environment, Proceedings of OEEPE Workshop on Airborne Laserscanning and Interferometric SAR for Digital Elevation Models, Stockholm, 1-3 March 2001,13 pp.

Sithole G., Vosselman G., (2004): Experimental comparison of filter algorithms for bare-Earth extraction from airborne laser scanning point clouds, ISPRS Journal of Photogrammetry and Remote Sensing, Vol. 59, pp. 85-101.

Wei H., Bartels M., (2006): Unsupervised segmentation using Gabor Wavelets and statistical features in LIDAR data analysis, $18^{\text {th }}$ International Conference on Pattern Recognition, Hong Kong, 20 August.

Vosselman G., (2000): Slope based filtering of laser altimetry data, International Archives of Photogrammetry and Remote Sensing, 33, (Part 3B), pp. 935-942.

Vosselman G., (2003): ISPRS test on extracting DEMs from point clouds "A comparison of existing automatic filters", Delft. http://www.itc.nl/isprswgIII-3/filtertest. 


\title{
Dwuetapowa filtracja w dziedzinie częstotliwości danych pochodzących z lotniczego skanowania laserowego
}

\section{Urszula Marmol}

\author{
Katedra Geoinformacji, Fotogrametrii i Teledetekcji Srodowiska \\ Akademia Górniczo-Hutnicza im. St. Staszica w Krakowie \\ Al. Mickiewicza 30, 30-059 Kraków \\ e-mail: entice@agh.edu.pl
}

\section{Streszczenie}

W artykule zaprezentowano metodę częstotliwościową filtracji danych pochodzących z lotniczego skanowania laserowego. Przegląd literatury ujawnia, że zostało opracowanych wiele metod usuwania elementów pokrycia terenu (budynki, roślinność itp.) w celu otrzymania z takich danych powierzchni topograficznej. Wszystkie metody oparte są na kryteriach geometrycznych, mówiąc dokładniej na określonym progu różnic wysokości pomiędzy dwoma sąsiadującymi punktami lub grupą punktów. Innymi słowy, powierzchnia topograficzna jest opisana $\mathrm{w}$ dziedzinie przestrzennej.

Proponowany algorytm bazuje na opisie powierzchni topograficznej w dziedzinie częstotliwości. Wykorzystano w nim dwa główne narzędzia, tj. szybką transformatę Fouriera (FFT) i filtry cyfrowe. Podstawowa zasada algorytmu opiera się na założeniu, że niskie częstotliwości odpowiadają za przebieg powierzchni topograficznej, natomiast wysokie częstotliwości są związane z elementami pokrycia terenu. Założenia ogólne metody zostały po raz pierwszy zaprezentowane w (Marmol i Jachimski, 2004). Wstępne rezultaty ujawniły pewne ograniczenia, w związku z tym został opracowany dwuetapowy algorytm filtracji. Filtr częstotliwościowy został zmodyfikowany w taki sposób, że inne parametry filtru są wykorzystane do wykrywania budynków, a inne do detekcji roślinności.

$\mathrm{W}$ pierwszym etapie przetwarzania danych przeprowadzana jest filtracja w celu wyeliminowania punktów związanych z budynkami. Wykorzystywany jest w nim filtr dolnoprzepustowy z parametrami właściwymi dla terenów zurbanizowanych. Celem drugiego etapu jest wyeliminowanie roślinności z wykorzystaniem filtru zaprojektowanego dla terenów leśnych.

Przedstawiony algorytm był testowany na danych pochodzących z testu ISPRS. Otrzymane wyniki zostały porównane zarówno $\mathrm{z}$ danymi referencyjnymi jak i z ośmioma metodami opisanymi $\mathrm{w}$ teście ISPRS.

Porównanie ilościowe wyników filtracji ze zbiorem danych referencyjnych wskazuje, że opracowany filtr generuje NMT o zadowalającej jakości. Dokładność NMT wygenerowanego przez algorytm częstotliwości osiąga średni poziom dokładności ośmiu metod opisanych w teście ISPRS. 
